ARTIBUS ASIAE

INSTITUTE OF FINE ARTS · NEW YORK UNIVERSITY

Quarterly of Asian Art and Archaeology for Scholars and Connoisseurs

Editorial Board:

Alexander C. Soper (editor-in-chief)

Richard N. Frye - Alexander B. Griswold - Stella Kramrisch

VOL. XXVII, 4

SEPAR A T U M

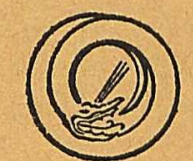

$\operatorname{MCMLXIV} / 65$

ARTIBUS ASI E PUBLISHERS - ASCONA - SWITZERLAND

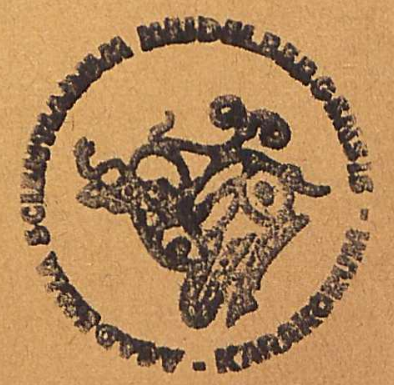


KARL JETTMAR

\section{THE SLAB WITH A RAM'S HEAD IN THE RIETBERG MUSEUM}

$\mathrm{T}$ he Rietberg Museum recently acquired an object (Figs. I a, b) which was said by the dealer to have come from the Iranian part of Azarbaijan. On request for the exact place of discovery, no more concrete information was given except that it came from a valley where more pieces of this kind were found. The object represents a slab of oolitic limestone, almost oval in shape, as seen from above. The upper side is absolutely flat and the side-walls are slightly convex forming a sharp edge against the upper plane. On one end, however, we see the head of a ram with magnificent horns, big enough to be regarded as representing a wild species (Ovis Ammon). The ends of the horns are flattened like curved ribbon. The eyes are two small knobs and two rills marls the nostrils on the rather plump muzzle. From muzzle to end the stone measures $38 \mathrm{~cm}$, the width from side to side is $25 \mathrm{~cm}$. The height of the flat part is II cm, of the front $14 \mathrm{~cm}$.

Dr. Leuzinger was so kind as to show me the piece, which had just been exhibited during my stay at Zurich in the beginning of March 1965 . I could tell her immediately that the object might be of importance, because in spite of its Iranian provenance, it positively belongs to a type which was hitherto known to exist only in the 'forest-steppes' east of the Urals.

\section{II}

The first fundamental study of specimens of the kind to which our object most certainly belongs ${ }^{\mathrm{I}}$ was made by Tallgren in $193^{2} 8^{2}$. Tallgren listed five of them (cf. Figs. 2-4). Three were found between the Urals and the River Tobol (near the tributaries Mias and Tura). Two were located rather peripherically, one on the Lower $\mathrm{Ob}$ and the other at Ronda, a village northnorth-west of Kazan. On account of the large horns Tallgren believed that they might represent Ovis Aries or some wild sheep of the steppes.

A more comprehensive survey was attempted by Dmitriev³, probably not much later. Dmitriev died during World War II, so that his study was not published until I948. The fact that the author was not able to give it a final revision makes it somewhat difficult to use. Under seven numbers, eight stones are listed. Five of them were found in the area of the River Mias, two neat the upper course of the River Tobol, one near the River Iseti. Dmitriev knew of the specimen from the Lower $\mathrm{Ob}$ now preserved in the Museum at Tomsk, but he overlooked the piece found at Ronda.

In $19^{64}$, Salnikov published descriptions of three more stones of this kind found during recent years ${ }^{4}$. One came from the Rayon Katakulskoye, I $50 \mathrm{~km}$ south-east of Chelyabinsk, the

x C. Pl.II, fig. I and 2.

2 Tallgren 1938 , Pp. Iog-II6.

3 Dmitriev I948, p. I9.

4 Salnikor ${ }^{2} 964$. 
second one from the surroundings of Shadrinsk, and the last one from Olkhovka, $30 \mathrm{~km}$ north of the town. The third object was found together with a stone pestle bearing two tills on the upper end, and a stone beater rather worn down at the bigger working-end.

All three pieces fit perfectly into the main area where these objects were found, the northern border of the steppes between the Ural mountains and the River Tobol.

The problem is that none of the stones was found at a datable site. From a typological point of view, the most important relatives of the slabs with the ram's heads are the "portable altars", most of which belong to the Sarmatian period4a.

Tallgren, however, who had just devoted a most valuable study to the "portable altars"s in which ram's-heads are sometimes used as ornaments, concluded that these slabs did not correspond to the main "Sarmatic" sub-group of the altars. Tallgren saw stylistic differences from the objects found in Sarmatic graves. The distribution was not the same, for the stone altars were spread out farther. Ram's head stones never appeared in graves as did the altars. Tallgren therefore attributed the slabs to "the period \pm 1000 B.C., i. e. the latter half of the so-called Andronovo culture" ".

Dmitriev apparently had never seen Tallgren's paper, as in those days the "ESA" was considered to be a dangerous publication. While making the same comparisons, he came to the opposite result. According to Dmitriev, the ram's-head slabs belong to the time between the 6th and 3 rd centuries B.C., i.e. the "Sauromatic" and the "early Sarmatic" periods".

Even today Salnikov fails to take note of Tallgren's study. He tries to confirm the dating of Dmitriev by means of rather scanty arguments. Thus he wrote that the stones from Karakulskoye might belong to the Sauromatian period, because a grave of this phase which had been excavated $60-70 \mathrm{~km}$ east of the site contained a pot, the shoulder of which showed the horns of rams in a rather schematic style of decoration ${ }^{8}$.

In fact, none of the arguments put forward by Tallgren has really lost its value. On the contrary, support is given to his position by the careful analysis of the famous knife of Turbino (found as early as 1890 west of the Middle Urals) made by Bader (Fig. 5$)^{9}$. The specimen belongs to the is th century B.C., or shortly thereafter.

This knife is decorated with the sculptures of three sheep. In spite of their small size, Russian zoologists believe them to be a reproduction of Ovis Ammon L. Wild sheep do not occur in this latitude, only far to the south in Iran, or in the mountains of Central Asia, e.g. in the Altai. According to Bader, some connection with Central Asia is most probable.

In any case, Turbino was not the optimal place to raise domestic sheep. So we are led to conclude that religious ideas coming from the South across the steppes inspired this realistic representation.

At this point we must recall that the ram's-head slabs east of the Urals may also depict wild sheep which do not in fact exist in the region. Possibly they belong to the same period and reflect the same foreign contacts which are to be recognized in the bronze knife of Turbino.

In any case, the knife of Turbino shows that objects of this kind, of a high artistic standard,

\footnotetext{
4a One further piece is described by K.F. Smirnov (Savromaty, Moscow I964, p. I65, Fig. 75/4). It comes from Kamardinovka, distt. Orenburg and is in fact the only one found in the Sarmatic area proper.

5 Tallgren 1937 . 6 Tallgren 1938 , p. 109 .

8 Kiparisova and Salnikov 1958 . 9 Bader 1964 , p. I23, fig. Ir 3. 


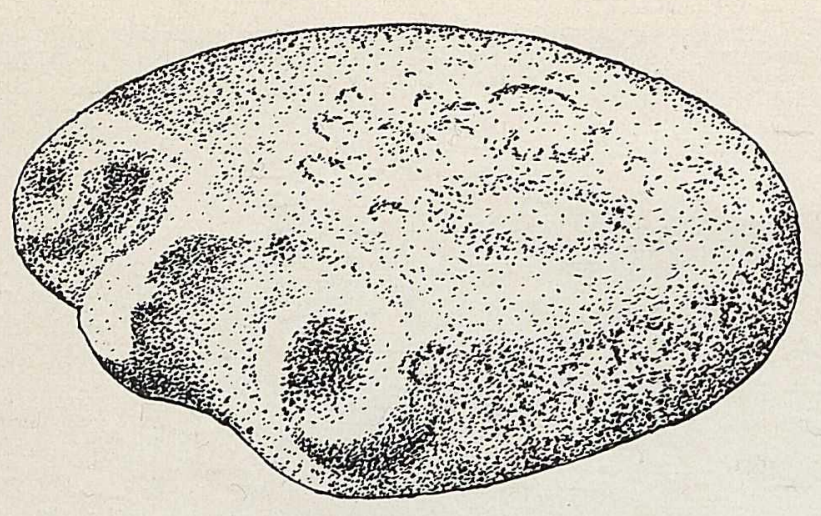

Fig. 2

Ram's-head slab. Vill. of Ronda, former district of Tsarevokokshaisk, Coll. Zausailov Helsinki. After Tallgren 1938

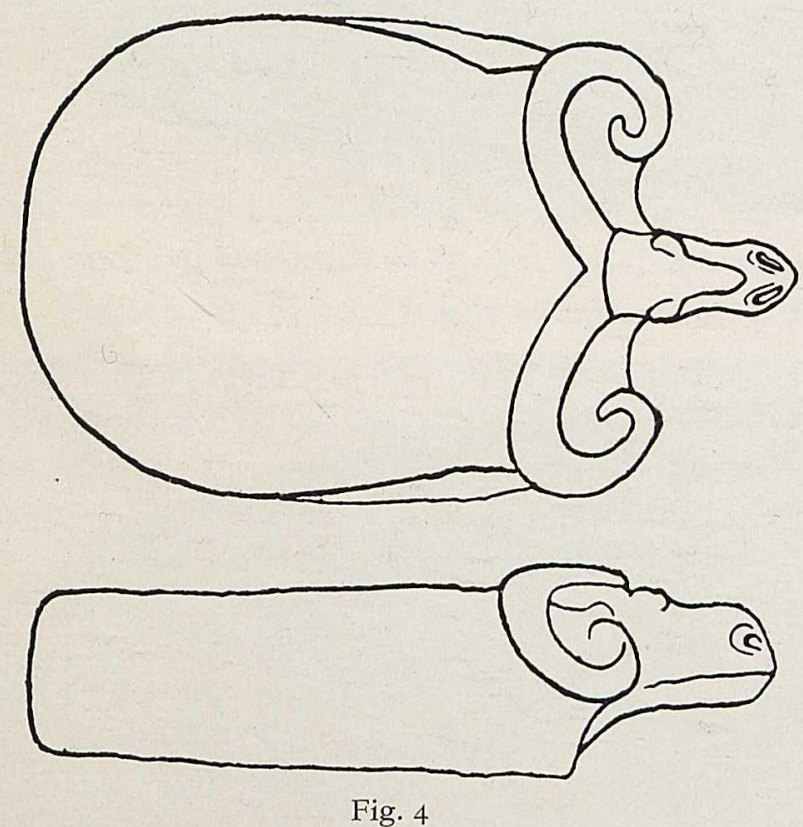

Ram's-head slab from the Vill. of Kladovoye, Dalmatov, ancient district of Shadrinsk, Eastern Urals. After Tallgren I938

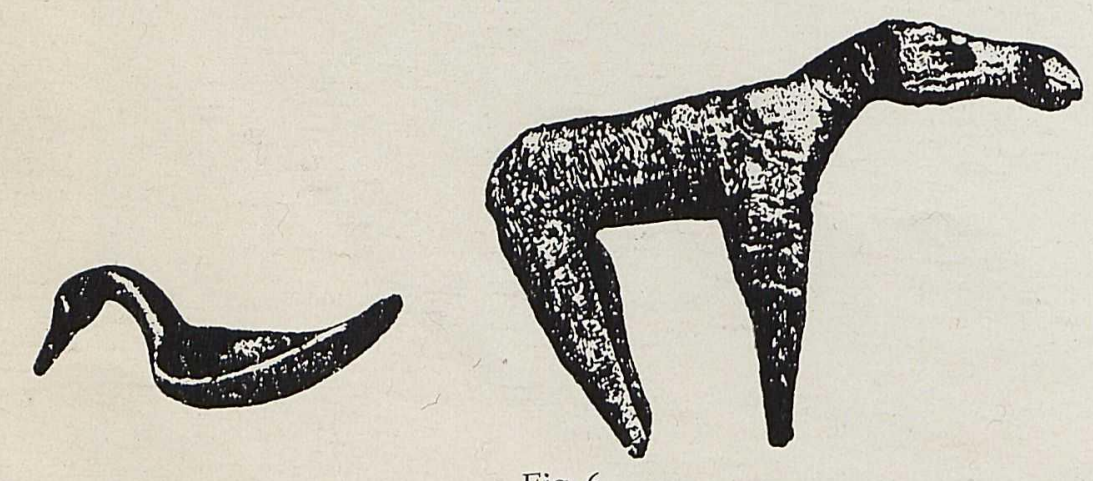

Fig. 6

Wooden sculptures from the Eastern Urals. Spoon and Vessel in shape of an elk. After Eding I 940

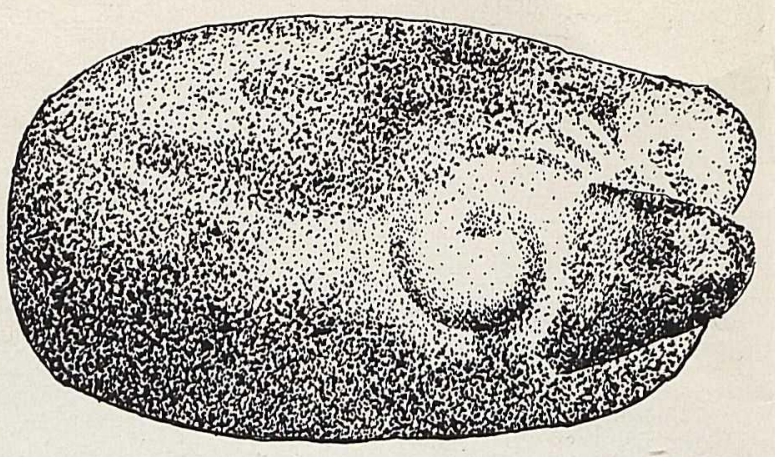

Fig. 3

Ram's-head slab from the district of Berezov, West-Siberia. Museum Tomsk. After Tallgren $193^{8}$

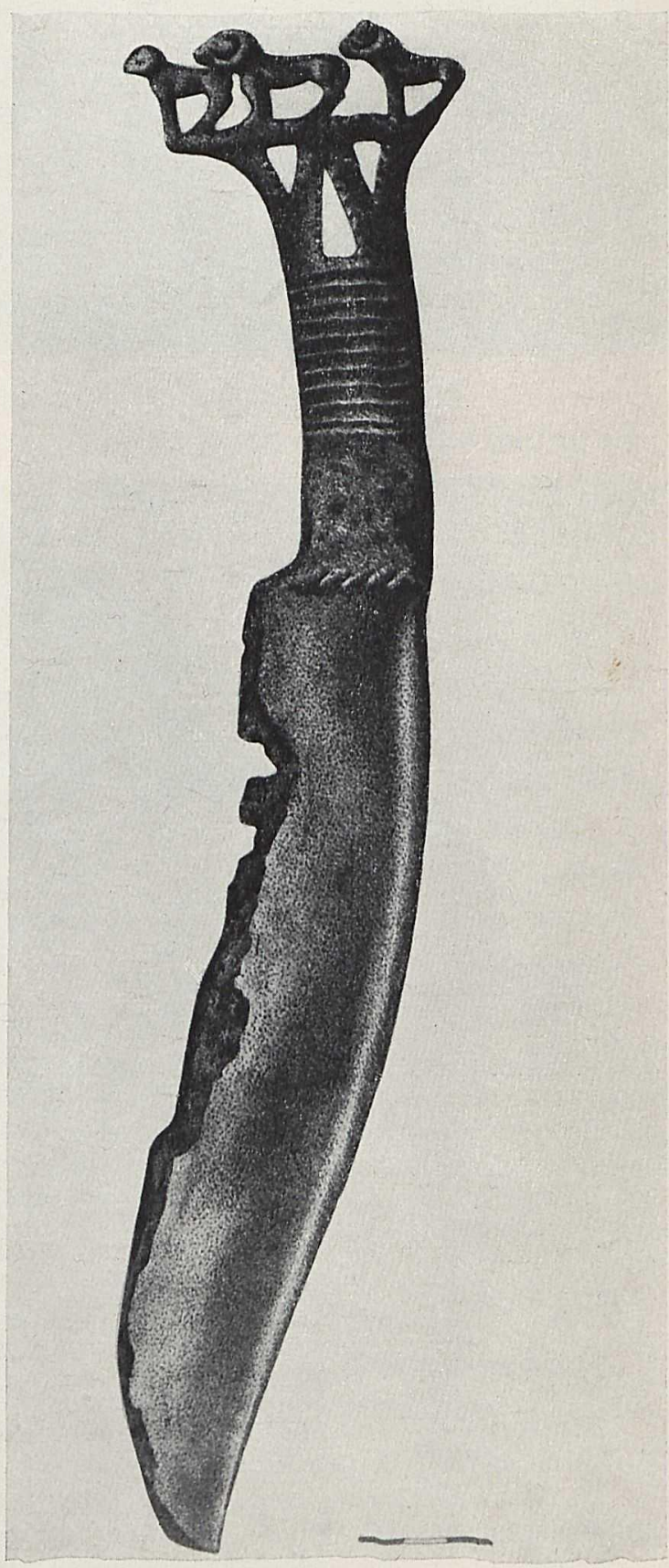

Fig. 5

Bronze Knife with standing sheep figures. Turbino, Perm. After Bader 1964 
occur far to the north as early as the second millennium. They need not be ascribed to the time of the Sarmatic nomads.

This, however, need not mean that the slabs are contemporary with the knife. They may belong to the end of the Andronovo period as proposed by Tallgren. Then they would be datable just half-way between the knife and the stone-altars of the Sarmatians.

\section{III}

What do we know about the use of these objects?

Observations made in the frozen tombs of the High Altai ro suggest that the stone altars were used for inhalation of hashish. Moreover, they may also have been useful for preparing colours for body-painting ${ }^{11}$. This is a combination already known from the incense-burners found in the Afanasievo culture, more than fifteen-hundred years earlier ${ }^{12}$.

From an artistic point of view, the slabs are surely related in some way to the altars. We could try to put them into the same functional sequence.

The second possibility is that they were used for dividing the meat of animals slaughtered in religious ceremonies at a holy place outside the village. Among the Dardic peoples of Northwest Pakistan who, in spite of their Indian language, show a number of archaic Iranian features, such a stone is called mitu - as is the man who had the task of dismembering the victim ${ }^{13}$. It plays an important role in the local beliefs, which would fully explain the artistic shaping of the slabs. Iranians today use millstones for this purpose which, however, are much bigger ${ }^{13 a}$.

The last possibility suggested by the piece from Olkhovka, found together with a pestle and a beater, is that some plants or substances were ground or pressed on such stones. We know that the Iranians had many ways of procuring intoxicating substances for religious ceremonies.

\section{IV}

Before we ask what the sudden appearance of a new ram's-head slab means, so far outside the established area of distribution, we must consider the possibility that the piece is the work of a forger, or was attributed by a dealer in antiquities to the wrong area.

In our case, forgery is hardly probable, as forgers would prefer to produce bronzes, not a rather clumsy stone. Moreover, it would be impractical to copy prototypes from Siberia while working for the 'Iranian market'.

It could be, however, that antiquities from Caucasia and Transcaucasia were exported in preSoviet or early Soviet times, perhaps by refugees. Such pieces have no proper market today, as a further supply is lacking, so they are perhaps sometimes added by the dealers to the highly lucrative Iranian stock ${ }^{14}$. But as for our ram's-head slab the possibility of such a "transfer" is rather theoretical; a refugee would have preferred to take with him small bronzes instead of a heavy stone.

\footnotetext{
10 Jettmar I964, p. 106. II DmitrieV I948, p. 20. I2 Lipskii I954. I3 Jettmar I96I a, p. 89.

13 a Verbal communication from Dr. Snoy.

14 Potratz $\mathrm{I}_{9} \mathrm{G}_{3}$ has just designated two pieces as falsifications. These I believe to be genuine, originating however from Caucasia (cf.Pl.XLI, p. 142, and fig. 2, p. I29). A specimen comparable to fig. 2, p. I 29 was found at Gurma-Gela, near Tiflis (cf. Lomatidze 1959, p.62, fig. $x / x$ ).

Generally speaking, it would be useful for Potratz to look at modern Soviet publications.
} 
Therefore, we may consider it more probable that the piece is genuine. Is it possible that such a distribution of the objects took place in the Bronze or Early Iranian Age? Do we know of any cultural connection between the 'forest-steppes' east of the Urals and Western Iran which could be combined with the proposed datings of the group?

a. Accepting the date of Dmitriev-Salnikov, we could artive at the Achaemenid period. Certainly, the dynasty always had in its service mercenaries coming from the steppes ${ }^{15}$, but we do not know of peoples from the Urals being frequently among them. The Sarmatic tribes of this territory had their field of operation in the Pontic area. Later on, among the mounted warriors of the Parthic period, troops of that area may have appeared, but this would already be almost outside the chronological frame-work indicated by the authors. In any case, no further arguments can be advanced for the moment.

b. When we try the earlier dating, following in the foot-steps of Tallgren, we find a more interesting background.

As Masson has recently shown ${ }^{16}$, a great part of the oasis of Turkmenia and adjacent Iran must have been in the hands of Indo-Aryan tribes as early as the first half of the second millennium B.C. During the second half, however, the density of population lessened remarkably. Evidently many tribes migrated to the east and south east into India. By this migration, the 'northern brothers' of the Indian tribes, the Iranians, were given the chance to expand. Originally they lived in the northern part of the steppes, especially in the forest-steppes east of the Urals where they can be identified as the bearers of the still agrarian Andronovo culture. The metallurgic centres of this population were the Altai in the east and the Urals in the west.

Two waves surged against the south. The first one spread over modern Turkmenia and reached the Iranian Plateau. Thereby, as a consequence of the assimilation of the local elements, settled or semi-nomadic peoples were formed - the Medes, Persians, Parthians, Aryans, Bactrians, etc. The second wave found its way blocked by its forerunner. So people adapted themselves to the environments of the dry belt and became horse-breeding nomads. Massagetae, Sacae and other Scythian tribes arose.

This theory has just been boldly and clearly formulated by Akishev ${ }^{17}$, and it received support from the investigation of the other more cautious Soviet scholars. Kuzmina ${ }^{18}$ draws our attention to the fact that excavations in so many sites of Turkmenia have always brought to light a certain quantity of sherds which may be derived from Andronovo pottery, partly as imports. The presence of these sherds is most abundant in the second half of the second millennium. E. Schmidt was right in speaking of a period of barbaric occupation in the history of Anau.

This view is shared by Litvinskii ${ }^{9}$. He, too, believes that the Iranians infiltrated not only by crossing the Caucasus but also by immigrating east of the Caspian Sea. The migration went on during the later Andronovo period tight into the first millennium. Litvinskii even thinks that trunnion-axes found in West Pakistan, (the author published an article about one of them ${ }^{20}$ ), trace back to an 'Uralic' prototype $2 x$ and were brought in by such tribes. An additional

15 The Iranian objects found in Pazyxyk were explained as the property of a man who had served in the Persian army and was familiar with the ceremonies of the Achaemenid court. CF. Jettmar I 95 I, p. 205.

I6 Masson-Romodin I964, pp. 4I-45.

17 Akisher $1_{96}$, pp. I2I-I36.

20 Jettmar 196 I b.

I 8 Kuzmina I964, pp. Is I-I 54.

21 Litvinskii I964, p. I 45 . Cf. Tallgren I 912.

I9 Litvinskii I962, pp. 287-300. 


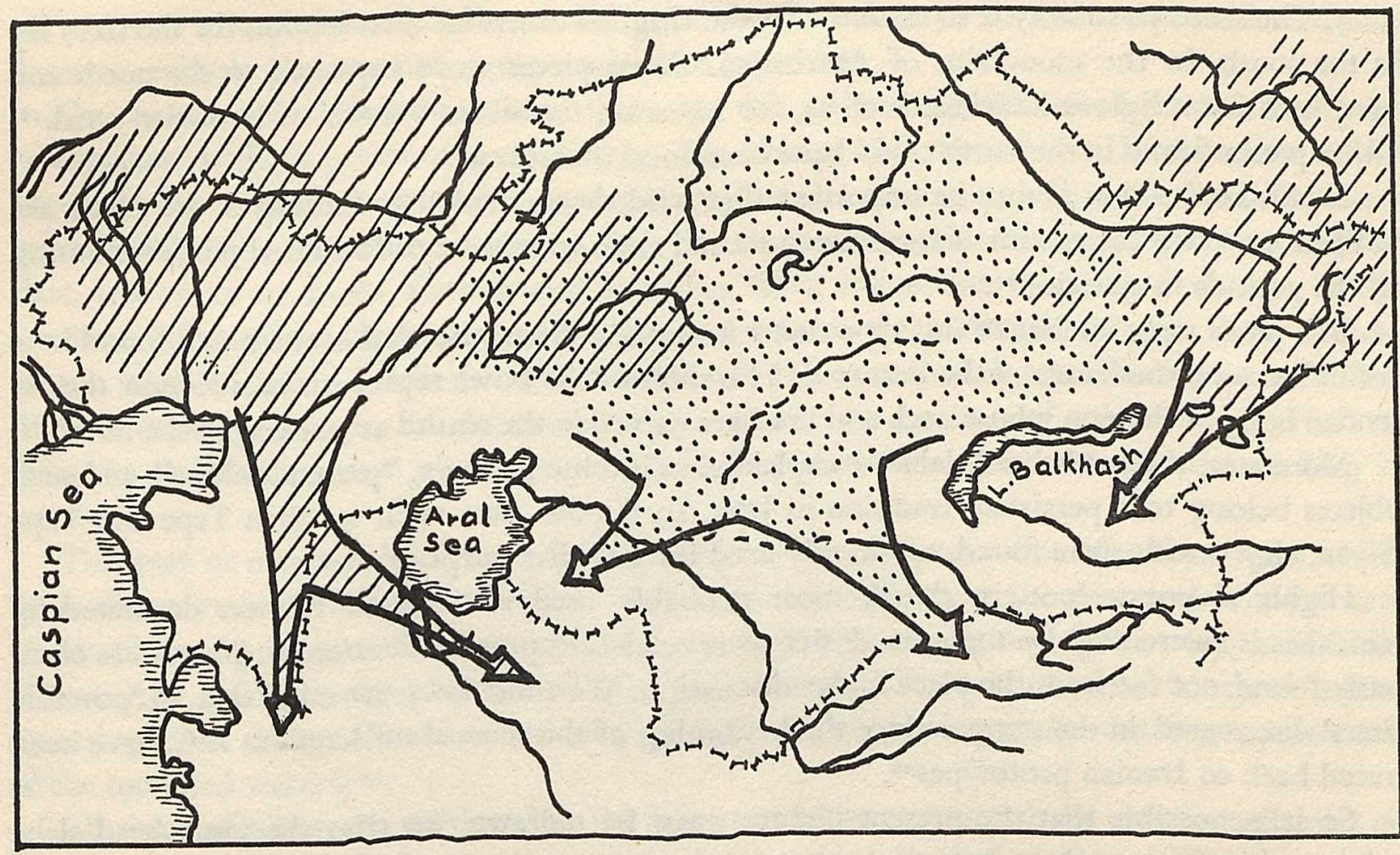

VIII] Western centre

$\therefore \because$ Middle centre

[?] Eastern centre

2 Movement of the Andronovo-people and their descendants

Supposed centres of the Andronovo culture and their extension according to Akisher I $96_{3}$

example, a bronze leaf-shaped blade with three central grooves found in Swat (West Pakistan) will soon be published in 'East and West'. It may be derived from an Uralic type of spear-heads.

In this connection it would be tempting to suppose that the ram's-head slab of Azarbaijan was brought by one of the immigrant tribes, coming from the eastern slopes of the Ural mountains.

But we have so far neglected the information given by the dealer that more stones of this type were available, five or six according to his words, in a remote valley of Azarbaijan. (He was, of course, not ready to trention the exact location of the valley because he intended to get hold of the whole stock before not only scientific but also mercantile interest had arisen.) If his information is correct, we have three possibilities:

I. Among the tribes infiltrating Iran during the late second or early first millennium B.C., one may have come froto the Urals. It brought with it a tradition of producing and using slabs of this kind for religious ceremonies. Thus a secondary centre for the distribution of this type grew up. Perhaps it was a tribe with an unknown language following the bulk of the "Iranians".

2. The second possibility seems to me rather theoretical; it is that the stones were produced in a distant centre and exported on the one hand to the area east of the Urals, on the other to Azarbaijan. 
3. The third possibility is to assume that the original centre of distribution for the slabs lay in the south, in the mountains of Azarbaijan. Some pieces were exported to the north and used here for religious activities such as, for instance, the silver vessels of Sassanian work ${ }^{22}$. Other pieces found in the north could have been local imitations.

In this connection it may be important that wild sheep, evidently lacking in the north, are indigenous to the mountains of Iran. Sheep served as an artistic motif for ritual purposes during all the periods in question ${ }^{23}$.

The piece most similar to this type that I know is a "ram"s-headed stone bowl, found in a coffin between the hands of the deceased. The sides of the bowl represent in side-view the extended body of the ram whose neck and head are carved in the round at one end of the bowl" ${ }^{24}$.

Moreover, the ram's-head slabs are explained as incense burners, "portable altars", and such objects belong to a persistent tradition in Iran. In famous sites such as Shah Tepe and Tepe Giyan, clay vessels were found, apparently used for a similar purpose.

Highly elaborate 'pottery altars', most probably used as incense burners decorated by rams'-heads, were sold by the same dealer to several European collections ${ }^{25}$. They were obviously found not far from the place under discussion. We must keep in mind that all 'portable altars' discovered in the steppes since the beginning of the second millennium B.C. have been traced back to Iranian prototypes ${ }^{26}$.

So it is possible that the present picture must be redrawn, so that the ram's-head slabs originated in Western Iran, even if they were known up to now only from a secondary centre.

It seems to me, that this apparently bold but quite reasonable thesis does not affect the general scheme of ethnic movements given a little earlier. Southern types may have expanded to the north just because tribes of the forest-steppes infiltrated the south. Whatever remains for the archaeologist of such a turbulent period are simply the destroyed and sacked cities in the south, like Hasanlu, and new acquisitions in the north, brought along by returning mercenaries ${ }^{27}$.

In the same way we may explain Caucasian peculiarities observed in the early Ananino culture $^{28}$. The Scythian kurgans of the early 6th century B.C. contain many treasures brought back by raiders in Assyria and Urartu; even in the later Altaic kurgans "souvenirs" from Iran were found 29 .

\section{VI}

These observations and considerations could be of some importance with relation to the still unsettled question of where and out of which components the Eurasian animal style originated. It is an old and cherished idea of many distinguished scholars that this style includes a factor of northern origin ${ }^{30}$. They have pointed out that wooden sculptures belonging to the Gorbunov culture and found in the peat-bogs of the Urals anticipate characteristic traits of the best masterpieces of this style (cf.Fig. 6) ${ }^{31}$. The similarities are more apparent than ever, because

22 Cf. I. A. Orbeli i K.V. Trever 1935 .

23 Big ram sculptures found in Azarbaijan are even supposed to belong to the medieval period. Brown $x 95$ r, p. I6r.

24 Porada $x_{9} 65$, p. 52, pl.8, below.

${ }_{25}$ Museum für Vor- und Frühgeschichte Frankfurt, Museum Leiden, Musées Royaux d'Art et d'Histoire, Bruxelles.

26 Kuzmina 1958, p. 28.

27 Dyson r 960 a, 1960 b.

30 e.g. Borovka 1928, p. 78 .

28 Zbrueva 1952 , pp. 164-169.

29 Jettmar I95 I, pp. 205.

31 Eding 1940 , Tallgren 1938 , p. I 17 . 
we are now in a position to discern an initial stage of the style in which the local wild and domestic animals play a much greater role than later on ${ }^{32}$.

On the other hand, it is fairly clear that even this earliest stage hitherto known is hardly to be explained without presuming very close connections with the advanced civilisations of the south. At the moment this southern component is under discussion among the Soviet scholars more frankly than ever. Chlenova, e.g., believes that artistic tendencies coming from the Near East, known to us from Kirkuk and Luristan, have influenced the Koban culture in the northern valleys of the Caucasus and the Karasuk culture of the Minusinsk basin. Both of these centres stimulated the artistic revolution in the whole belt of the steppes. Chlenova even thinks that the typical technique of the animal style, namely the forming of animals' bodies out of cylinders and hemispheres, was originally created by the seal-cutters in the South, working in steatite ${ }^{33}$.

This may or may not be correct; in any case, a strong influence from the Near East, which by tradition made liberal use of animal motifs, was needed before the taboo was broken that restricted the representation of animals in the early steppes. Here, during the early and middle Bronze Age, animal images were evidently connected with the cult of some deities. A fundamental spiritual change must have taken place before they could serve for the magic protection of the mounted warrior ${ }^{34}$.

All these affinities are evident but we have not hitherto grasped the actual mechanics of contacts nor determined the precise trade and migration routes. Chlenova thinks there must have been some "almost unknown" centres halfway between Luristan and Karasuk, perhaps in the area of modern Afghanistan.

If it is proved by additional pieces and stratigraphic observation that the ram's-head slab found in Western Iran is genuine and belongs to an early period, then we may hope to find one concrete link between two definite areas. We could then locate one of the highways by which southern ideas moved north, stimulating the rise of the nomadic horse-breeders.

\section{BIBLIOGRAPHY}

Akishev, K.A. (i G. A. Kushaev): Drevniaia kultura sakov $i$ usunei doliny reki Ili. Alta-Ata $196_{3}$.

Antonini, Chiara Silvi: Preliminary Notes on the Excavation of the Necropolises found in Western Pakistan. East and West, N.S., vol. 14, Nos. I-2, Pp. 13-26. March-June 1963.

Bader, O.N.: Drevneishie metallirgi Urala. Moscow 1964 .

Borovka, G.: Scytbian Art. New York 1928.

Brown, T. B.: Excavations in Azarbaijan, 1948. London $195 \mathrm{x}$.

Chlenova, N. (N. T'chlenova): L'art animalier de l'époque Scythique en Sibérie et en Pontide. VIe Congrès international des sciences préhistoriques et protohistoriques - Les rapports et les informations des archéologes de l'URSS. Moscou I 962 .

Dmitriev, P.A.: Zhertvennye kamni Zauralia. KSIIMK XIX, pp. I 2-2I, 1948.

Dyson, R.H. Jr.: Where the Golden Bowl of Hasanlu was found: Excavations Near Lake Urmia which Throw Light on the Little-Known Mannaeans. Part I, in: Illustrated London Nens I960 (Jan. 23), Pp. I32-134. I960a;

32 Ilinskaya 1965 .
33 Chlenova Ig62, pp.9-II.
34 Jettmar 1964, p. 238. 
: The Golden Bowl and the Silver Cup - Treasures with a Dramatic History and a Rich Significance: Excavations at Hasanlu, Near Lake Urmia. Part II, in: Illustrated London News I960 (Feb. I3), pp. 250-251. I960b.

Eding, D. N.: Reznaia skulptura Urala. Trudy GIM X. Moscow i940.

Ilinskaia, V.A.: Nekotorye motivy ranneskifskogo zverinogo stilya. $S A$, pp. 86-107. 1965.

Jettmar, Karl: The Altai before the Turks. Bulletin of the Museum of Far Eastern Antiquities, No. 23, pp. 135-223. Stockbolm I95 I.

: Ethnological Research in Dardistan 1958. Preliminary Report. Proceedings of the American Philosophical Society, vol. ros, No. r, pp.79-97. I96ra;

: Bronze Axes from the Karakoram. Proceedings of the American Philosopbical Society, vol. ros, Nr. I, pp.98-104. $196 \mathrm{Ib}$;

: In den Jahren I955 bis 1962 erschienene Werke zur frühen Nomadenkunst der asiatischen Steppen. Kunstgeschichtliche Anzeigen, N.F., 5.Jg., S. I84-197. Graz-Köln 1961/1962;

: Ausbreitungsweg und sozialer Hintergrund des eurasiatischen Tierstils. Mitteilungen der Anthropologischen Gesellschaft Wien, XCII (Festschrift F.Hančar), S. 176-191. 1962;

: Die Frühen Steppenvölker, Baden-Baden I964.

Kiparisova, N.P. i K.V.Salnikov: Savromatskoe pogrebenie bliz g. Troitska. SA 2, pp. 246-25 I. 1958.

Kuzmina, E. E.: O iuzhnykh predelakh rasprostraneniia stepnykh kultur epokhi bronzy v Srednei Azii. Pamiatniki kamennogo i bronzovogo vekov Evrazii, pp. I4I. I58. Moscow 1964.

Lipskii, A.N.: Afanasievskie pogrebeniia v nizoviakh rek Esi i Tei (Kkakassiia). KSIIMK 54, pp. 89-300. 1962.

Litvinskii, B. A.: Pamiatniki epokhi bronzy i rannego-zheleza Kairak-Kumov. Drevnosti Kairak-Kumov, pp. 89-300. I962.

Litvinskii, B.A.: Tadzhikistan i Indiia. Primery drevnikh sviazei i kontaktov. Indiia v drevnosti, pp. 143-165. Moscow I 964 .

Lomtatidze, G.A.: Rezultaty i perspektivy arkheologicheskogo izucheniia goroda Tbilisi. $S A$ 4, Pp. 6I-73. I959.

Masson, V.M. i V. A. Romodin: Istoriia Afganistana, t.I. Moscow ig64.

Orbeli, I. A. and Trever, K.V.: Sasanidskii metall. Moscow-Leningrad I935.

Porada, Edith: The Art of Ancient Iran - Preislamic Cultures. New York I965.

Potratz, Johannes A.H.: Über ein Corpus Aerum Luristanensium. Iranica Antiqua III, 2, S. 1 24-I47. 1963.

Raushenbakh, V.M.: Srednee Zaurale v epokhu neolita i bronzy. Trudy Gosudarstvennogo Istoricheskogo Mureia, v. 29. Moscow i956.

Salnikov, K.V.: Bronzovyi vek Iuzhnogo Zauralia. Materialy $i$ issledovanija po arkbeologii SSSR, Moscow-Leningrad I95I. Vol.21, pp.94-I5I;

: Nakhodki na Iuzhnom Urale. SA r, pp.313-315. 1964.

Tallgren, A.M.: Die kupfernen Flachäxte mit seitlichen Zapfen. Zeitschrift der Finn. Altertumsgesellschaft,

Bd. XXVI, S. I-8. 1912;

: "Portable Altars". ESA XI, pp. 47-68. I937;

: Some North-Eurasian Sculptures. ES A XII, pp. 109-135. 1938.

Zbrueva, A.V.: Istoriia naseleniia Prikamia v ananinskuiu epokhu. Materialy $i$ issledovanija po arkheologii SSSR, vol. 30. Moskow I9s2.

Abbreviations

ESA - Eurasia septentrionalis antiqua. Helsinki.

KSIIMK - Kratkie soobshcheniia (o dokladakh i polevykh issledovaniiakh) Instituta istorii materialnoi kultury. Moskva-Leningrad.

SA

- Sovetskaia arkheologiia. Moskva-Leningrad ili Moskva.

Trudy GIM - Trudy gosudarstvennogo istoricheskogo muzeia. Moskva. 